\title{
Sweetpotato Virus Disease (SPVD): Distribution, Incidence, and Effect on Sweetpotato Yield in Peru
}

\author{
D. L. Gutiérrez, S. Fuentes, and L. F. Salazar, International Potato Center (CIP), Lima 12, Peru
}

\begin{abstract}
Gutiérrez, D. L., Fuentes, S, and Salazar L. F. 2003. Sweetpotato virus disease (SPVD): Distribution, incidence, and effect on sweetpotato yield in Peru. Plant Dis. 87:297-302.

Sweetpotato virus disease (SPVD), the most important disease affecting sweetpotato (Ipomoea batatas (L.) Lam), is caused by the synergistic interaction of the aphid-transmitted Sweetpotato feathery mottle virus (SPFMV) and whitefly-transmitted Sweetpotato chlorotic stunt virus (SPCSV). In this study, SPVD was the main disease in the Cañete Valley, the major sweetpotato-producing area in Peru. Studies on virus incidence showed that SPCSV and SPFMV were the most frequently identified viruses in Cañete Valley. Symptoms of different severity were associated with isolates of both viruses involved in the SPVD. Over $80 \%$ of plants infected with both SPFMV and SPCSV showed the symptoms (leaf reduction and deformation, vein clearing or mosaic, and stunting) typically attributed to SPVD elsewhere. SPFMV did not significantly affect the yield of the sweetpotato cultivars Jonathan and Costanero, but infection of these cultivars by SPCSV was associated with significant yield reduction. Double infection by the two viruses resulted in SPVD and greater yield reduction than for either alone. These results demonstrate that SPFMV and SPCSV interact synergistically and that the severity of SPVD symptoms also depends on the particular isolate of each virus.
\end{abstract}

Additional keywords: synergistic virus interactions, yield reductions

Virus diseases are important constraints for sweetpotato (Ipomoea batatas (L.) Lam.) production: more than half of the yield losses have been attributed to virus diseases $(21,26)$. More than 20 viruses have been reported to infect sweetpotato, but only a few have been characterized $(6,11,25)$. The high viral incidence in sweetpotato crops is due to the planting of infected stem cuttings (virus source) and the secondary spread of viruses by aphid and whitefly vectors in sweetpotato plantings. Knowledge on the distribution, economic impact, and control of sweetpotato viruses is still limited (8). In many cases, infection of sweetpotato by two or more different viruses causes greater damage than does infection by each of the viruses separately. This synergism has been documented for sweetpotato virus disease (SPVD; 18,22) caused by both the aphidtransmitted potyvirus Sweetpotato feathery mottle virus (SPFMV) and the whiteflytransmitted crinivirus Sweetpotato chlorotic stunt virus (SPCSV; 6), and for chlorotic dwarf (CD) disease of sweetpotato caused by SPFMV, SPCSV, and Sweetpotato mild speckling virus (SPMSV; 13).

Corresponding author: L. F. Salazar
E-mail: 1.salazar@cgiar.org

Accepted for publication 17 October 2002.

Publication no. D-2003-0116-02R

(C) 2003 The American Phytopathological Society
SPVD is the most harmful disease of sweetpotato, severely reducing the yield of affected plants. SPVD is common throughout East and West Africa (Cameroon, Ghana, Kenya, Nigeria, and Uganda), and also has been reported from Asia (Israel, Taiwan, and China) and America (United States of America, Argentina, Brazil, and Peru) (2). Infection by SPFMV alone usually causes only mild or no symptoms, whereas more discernable symptoms are associated with SPCSV (18). Symptoms caused by SPVD include leaf reduction and deformation, vein clearing or mosaic, and stunting of plants $(2,11,18)$. SPVD causes significant yield reductions, but does not affect storage root quality $(18,21,24)$.

SPVD-like disease emerged in Peru after the increase of whitefly populations in 1997-98. Preliminary surveys carried out at the end of 1998 confirmed, for the first time, the presence of SPCSV in the Cañete Valley (150 km south of Lima), the major sweetpotato-producing area in Peru (27). The present study demonstrates that SPVD is the main virus disease affecting the sweetpotato crop in Peru's Cañete Valley.

\section{MATERIALS AND METHODS}

Distribution and incidence of SPCSV and SPVD. A survey was carried out on commercial sweetpotato fields in the Cañete Valley, south of Lima, Peru (Fig. 1). Twenty-two fields, with an area of at least 1 ha and plants 1.5 to 4 months old, were selected in the six districts in this valley. Between 11 and 20 January 1999, 90 samples were collected from each field (total $=1,980$ samples). Two leaves were collected from each plant, one from the top and one from the middle part of the plant. Samples then were tested for SPFMV, SPCSV, SPMSV, Sweetpotato latent virus (SwPLV), Sweetpotato mild mottle virus (SPMMV), Sweetpotato chlorotic fleck virus (SPCFV), and C-6 (a new flexuous rod virus) using enzyme-linked immunosorbent assay on nitrocellulose membranes (NCM-ELISA; (9) at the International Potato Center (CIP)'s virology laboratory. Positive and negative detection was determined by visual assessment where purple color reaction was recorded as positive.

Extracts from virus-free plants of several sweetpotato cultivars and indicator plants (I. setosa Ker. and I. nil (L.) Roth, which react to virus infection with characteristic symptoms over a wide range of environmental conditions) were used as negative controls. Extracts from I. setosa, I. nil, and Nicotiana benthamiana Domin, used for the propagation of each virus (from CIP's collection), were utilized as positive controls in NCM-ELISA.

SPFMV monoclonal antibodies (MAbs) prepared against isolate SPV-I from Nigeria and a recombinant polyclonal antiserum for SPCSV-KyCP and MAb mixes 1 and 2, which detect SPCSV from East Africa and Nigeria (32), were kindly provided by G. Thottappilly (IITA, Ibadan, Nigeria) and J. Vetten (Federal Biological Research Center, Institute of Biochemistry, Agriculture and Forestry, Braunschweig, Germany), respectively. Goat anti-rabbit (GAR) and goat anti-mouse (GAM) antibodies, conjugated with alkaline phosphatase, were acquired commercially (Bio-Rad Laboratories, Hercules, CA). Polyclonal antisera for other viruses were produced at CIP (8) and used diluted 1:1,000 ( $\mathrm{vol} / \mathrm{vol}$ ) (a dilution previously determined to prevent reactions due to cross-reactivity between viruses in the same group; 20) in Tris-buffered saline (TBS), pH 7.5, containing 2\% milk, whereas MAb mix 1 and mix 2 were diluted 1:300 (vol/vol) and GAR, GAM, and MAb SPV-I were diluted 1:10,000 (vol/vol).

Only the polyclonal antiserum for SPCSV-KyCP was cross absorbed with extracts from virus-free sweetpotato plants to eliminate antibodies that react to plant proteins as follows: leaves were macerated in TBS, $\mathrm{pH} 7.5$, containing $0.2 \% \mathrm{Na}_{2} \mathrm{SO}_{3}$ 
and $2 \%$ milk ( $1 \mathrm{~g}$ of tissue per $30 \mathrm{ml}$ of buffer). The extract was subjected to centrifugation $(10,000 \times g$ for $10 \mathrm{~min})$ and the antiserum was added to it (final dilution $1: 1,000, \mathrm{vol} / \mathrm{vol})$. The solution was mixed, incubated at $37^{\circ} \mathrm{C}$ for $1 \mathrm{~h}$, then added to the membrane blocked with $2 \%$ powdered milk (9).

Infectivity assays. To establish the differences among the SPFMV isolates, transmission tests were carried out. Sap from test plants was homogenized and diluted in $0.05 \mathrm{M}$ potassium phosphate buffer, $\mathrm{pH} 7.2$, containing $0.2 \%$ sodium sulfite and rubbed on leaves of $N$. benthamiana, I. nil and I. setosa.

Effect of SPFMV and SPCSV infection on sweetpotato yield. Virus-free cvs. Jonathan and Costanero were provided by CIP's germ plasm bank (Lima, Peru). These experimental cultivars were selected by their availability as virus-free (hereafter referred as healthy) cultivars and resistance to Meloidogyne incognita. SPFMV was isolated from SPVD-affected sweetpotato plants and SPCSV from SPCSV-affected plants, collected in Cañete. The obtained M2-44 isolate of SPFMV was maintained by mechanical inoculation in $I$. nil, and the M2-47 isolate of SPCSV was maintained by grafting to I. setosa. Stem-cuttings of Jonathan and Costanero were graft-infected with SPFMV and SPCSV. For SPVD (SPFMV + SPCSV), double graft inoculation was done. Mechanical and graft transmissions were carried out as described (9).

The experiment was conducted between February and July 2000 in Cerro Cohete Lot, Imperial District, Cañete Valley. Two cultivars and four levels of viral infection were evaluated in a randomized complete block design with three replications. This trial consisted of 100 plants per plot (four rows of 25 cuttings each) planted $0.30 \mathrm{~m}$ apart on rows spaced $0.90 \mathrm{~m}$ apart. Around the perimeter of the experiment, corn was planted and an integrated pest management program (10) was conducted to control whitefly and aphid populations to reduce virus transmission. During the trial, symptoms (purpling, yellowing, stunting, leaf reduction, and so on) were recorded by visual inspection to associate them with specific virus infection in each treatment.

Agronomic characteristics such as "ground cover" (portion of ground covered

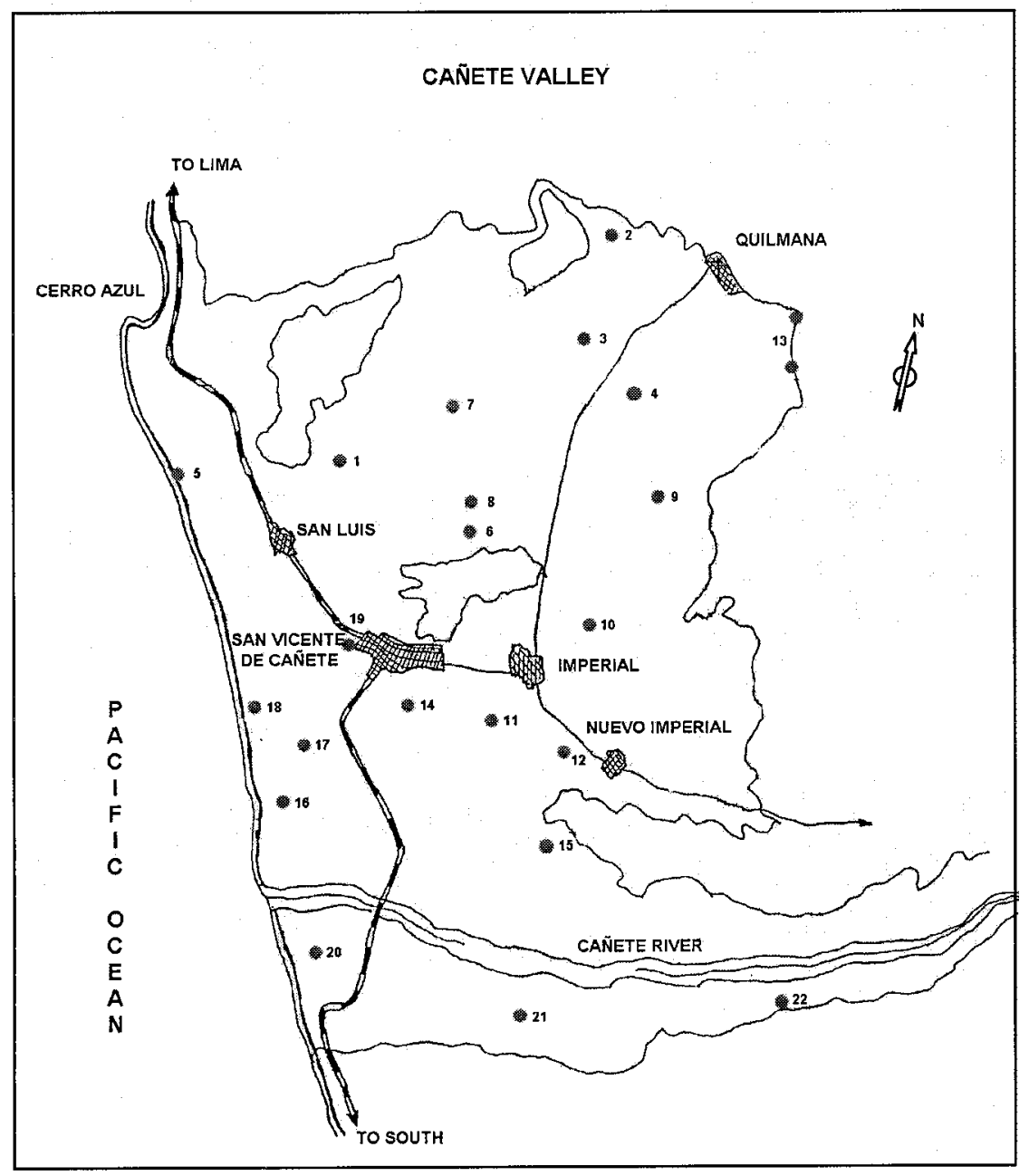

Fig. 1. Locations of the surveyed sweetpotato fields in Cañete Valley, Peru (11 to 20 January 1999). Numbered fields were located in the following districts: 1, Cerro Azul; 2 to 4, Quilmaná; 5 and 6, San Luis; 7 to 10, Imperial; 11 to 13, Nuevo Imperial; and 14 to 22, San Vicente.

by green foliage), number of main branches, and main branch length were evaluated on 12 plants selected at random per plot (6 plants per inner row). Ground cover was measured 46 days after planting (dap), using a wooden frame with dimensions of 0.90 by $0.30 \mathrm{~m}$ (corresponding to the length between rows and plants, respectively). The area inside the wooden frame was divided with wicks, making a mesh with square sectors of 10 by $10 \mathrm{~cm}$. The wooden frame was suspended in the air over the plant, and the number of squares filled by the foliage area was counted. The number and length of main branches were evaluated a week before harvest (160 dap). Weight of fresh foliage and weight and number of total and marketable (between 100 to $600 \mathrm{~g}$ ) storage roots were recorded for plants of the two inner rows (approximately 50 plants per plot) at harvest (167 dap). Data were subjected to analysis of variance and statistical significant differences among means of the levels of each factor were determined by a least significant difference test at $P<0.05$ (SAS version 6.12, SAS Institute Inc., Cary, NC).

\section{RESULTS}

Distribution and incidence of SPCSV and SPVD. The most frequently detected viruses were SPCSV and SPFMV, alone and in double infection (Table 1). Dual infection by these two viruses (SPVD) occurred in 20 of 22 locations surveyed. SwPLV and SPMSV were detected at low incidence alone and in mixed infection with SPFMV and SPCSV. Mixtures of three viruses were detected in 12 samples, of which 10 were infected with SPFMV, SPCSV, and SwPLV and 2 with SPFMV, SPCSV, and SPMSV. SPMMV, SPCFV, and C-6 were not detected in any sample. Virus incidence and distribution are summarized in Table 1.

Of the 1,980 samples collected, 870 showed diverse symptoms in the field. However, not all plants showing symptoms reacted positively in NCM-ELISA and some symptomless plants reacted positively. The most common symptoms observed in the field were color deviations (chlorosis, vein clearing, chlorotic spots, mottle, mosaic, and yellowing) and abnormal pigmentation (purpling rings or spots). Other symptoms included deviations in normal shape, size, and texture of leaves and stems (blistering, leaf curling, leaf distortion, leaf narrowing, proliferation of buds, and stunting). Of 187 samples that reacted only with SPFMV, 116 showed purple spots, purple rings, chlorosis, and chlorotic spots and, in some cases, leaf curling and blistering. Of 286 samples that reacted only with SPCSV, 156 showed purple spots, yellowing and, in some cases, stunting. Of 171 plants reacting to both SPFMV and SPCSV, 141 showed the characteristic symptoms of SPVD (Fig. 2). 
The presence of other, as yet unidentified viruses in the symptomatic plants was ruled out because several of these samples were grafted to I. setosa and I. nil and no symptoms developed, nor could a virus be observed by the electron microscope.

Effect of SPFMV and SPCSV infection on sweetpotato yield. Three SPFMV isolates (M2-41, M2-44, and C-18) were obtained from SPVD-affected sweetpotato plants by mechanical inoculation to I. nil. These isolates differed in symptom severity expressed in I. nil and in their reaction against polyclonal and monoclonal antibodies used in NCM-ELISA (Fig. 3). The M2-44 isolate caused the most severe symptoms in I. nil and infected N. benthamiana. There were no differences in the symptoms in I. setosa. Two SPCSV isolates (M2-47 and M2-62) were obtained from SPCSV-affected sweetpotato plants by grafting to I. setosa. Isolate M2-62 exhibited the most severe symptoms (stunting, yellowing, and leaf deformation) in $I$. setosa, whereas the M2-47 isolate caused only a mild chlorosis (Fig. 3).

Jonathan and Costanero sweetpotato plants inoculated separately with one of the three isolates of SPFMV or the M2-47 isolate of SPCSV did not develop any symptoms, but plants infected with SPCSV and SPFMV developed symptoms characteristic of SPVD. The most severe symptoms were caused by the double infection of isolate M2-44 of SPFMV with M2-47 of SPCSV (Fig. 4).

The interaction between cultivar and viral infection were not significant, suggesting that both cultivars have a similar yield response to infection (Table 2). On the other hand, significant differences were found between cultivars and among levels of viral infection. When compared with healthy plants, the agronomic characteristics of SPFMV-infected plants did not differ significantly $(P>0.05)$; however, differences were observed with SPCSV-infected and SPVD-affected

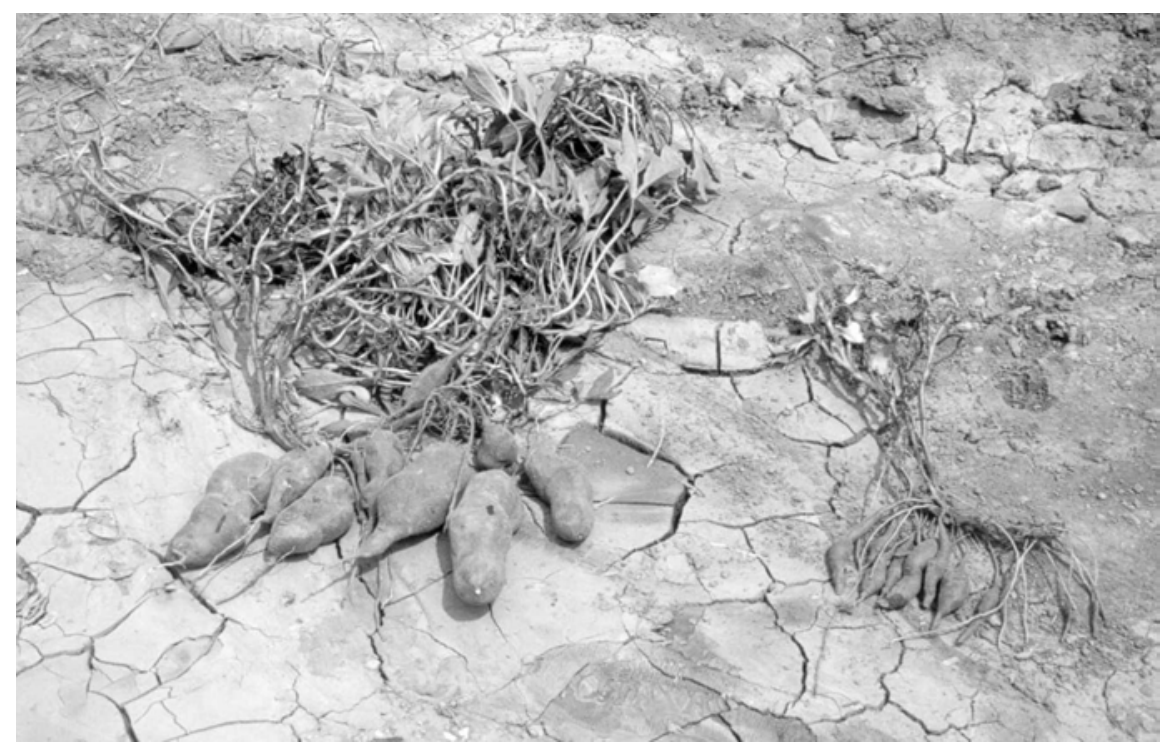

Fig. 2. Sweetpotato plants from a farmer's field in Cañete, Peru, apparently healthy (left) and affected with sweetpotato virus disease (right).

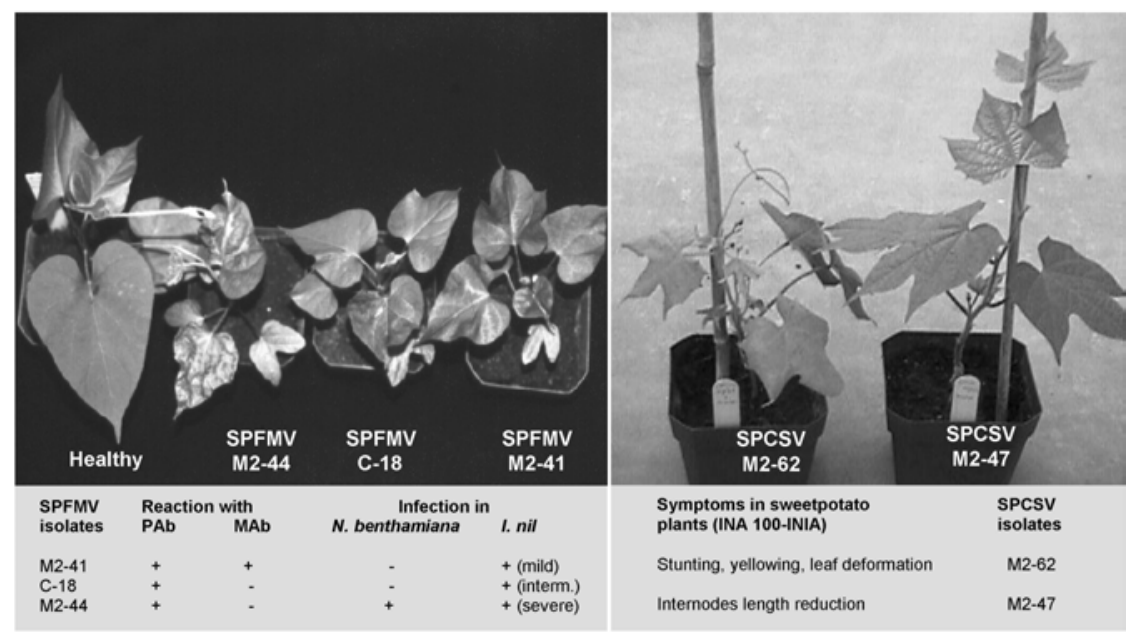

Fig. 3. Symptoms induced by Sweetpotato feathery mottle virus (SPFMV) and Sweetpotato chlorotic stunt virus (SPCSV) isolates in indicator plants. Left: Reaction of Ipomoea nil to SPFMV isolates (top) and their respective serological and symptomatological differentiation (bottom). Right: Reaction of I. setosa to SPCSV isolates (top) and symptoms observed in sweetpotato plants from where the viruses were isolated (bottom).

Table 1. Serological detection of viruses in sweetpotato samples collected from surveyed fields in Cañete Valley, Peru (11 to 20 January 1999$)$

\begin{tabular}{|c|c|c|c|c|c|c|c|c|c|c|}
\hline \multirow[b]{2}{*}{ Districts } & \multicolumn{3}{|c|}{ Number } & \multirow[b]{2}{*}{ Incidence $(\%)^{y}$} & \multicolumn{6}{|c|}{ Number of samples positive with ${ }^{u}$} \\
\hline & Fields $^{v}$ & Collected $^{\mathrm{w}}$ & Infected $^{x}$ & & SPCSV-12 & SPCSV-2 $2^{z}$ & SPFMV & SwPLV & SPMSV & SPVD \\
\hline Cerro Azul & 1 & 90 & 46 & 51.11 & 37 & 0 & 21 & 1 & 1 & 13 \\
\hline Quilmaná & 3 & 270 & 157 & 58.15 & 112 & 3 & 94 & 8 & 2 & 53 \\
\hline San Luis & 2 & 180 & 97 & 53.89 & 75 & 0 & 53 & 20 & 1 & 25 \\
\hline Imperial & 4 & 360 & 152 & 42.22 & 117 & 0 & 76 & 2 & 0 & 43 \\
\hline \multicolumn{11}{|l|}{ Nuevo } \\
\hline Imperial & 3 & 270 & 46 & 17.04 & 29 & 0 & 22 & 3 & 0 & 8 \\
\hline San Vicente & 9 & 810 & 207 & 25.56 & 104 & 3 & 111 & 13 & 10 & 29 \\
\hline Total $(\%)$ & 22 & 1,980 & 705 & 35.61 & $474(24.0)$ & $6(0.3)$ & $377(19.0)$ & $47(2.4)$ & $14(0.7)$ & $171(8.6)$ \\
\hline
\end{tabular}

u Viruses detected by enzyme-linked immunosorbent assay on nitrocellulose membranes. SPCSV = Sweetpotato chlorotic stunt virus, SPFMV $=$ Sweetpotato feathery mottle virus, SwPLV = Sweetpotato latent virus, SPMSV = Sweetpotato mild speckling virus, SPVD = sweetpotato virus disease $($ double infection of SPFMV with SPCSV). Sweetpotato mild mottle virus, Sweetpotato chlorotic fleck virus, and C-6 (a new flexuous virus) were tested but not detected in any sample.

${ }^{v}$ Number of surveyed fields.

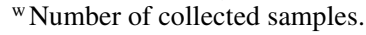

${ }^{\mathrm{x}}$ Number of infected samples.

${ }^{y}$ Percent viral incidence.

${ }^{\mathrm{z}}$ Mix of monoclonal antibodies to detect SPCSV serotypes; mix 1 = reacts with East African isolates and mix $2=$ reacts with other isolates outside of East Africa. 
plants (Table 2). Main branch length also was significantly different for SPVDaffected plants compared with healthy plants, but this agronomic characteristic did not differ for SPFMV- compared with SPCSV-infected plants. The number of main branches was not significantly different for any treatment. Yield of total storage roots was directly related to the yield of fresh weight of foliage in cvs. Jonathan and Costanero. SPFMV had no significant effect on yield of total storage roots, but the effect of SPCSV and SPVD in both cultivars was significantly different (Table 2 and Fig. 5). Yield reduction ranged from 33.98 to $43.55 \%$ (for SPCSV) and from 65.25 to $72.24 \%$ (for SPVD), depending on the cultivar. The yield of healthy plants was 2.8 to 4.5 times higher than that of SPVD-affected plants (Fig. 5). The variability coefficient was highest $(38.60 \%)$ for fresh weight of foliage, with a range of 8.38 and $27.68 \%$ for the other agronomic characteristics (data not shown).
SPFMV-infected Jonathan and Costanero plants did not show foliage symptoms under field conditions, but SPCSV caused purpling in basal leaves only in Jonathan plants. SPVD-affected plants developed the characteristic symptoms for this disease in both cultivars.

Presence of other viruses during trial was ruled out by visual inspection and serological detection to reported viruses in Peru $(12,16,17)$.

\section{DISCUSSION}

It was found, for first time, that SPVD occurs widely in the Cañete Valley of Peru as the most important virus disease on sweetpotato. During this first large survey, both components (SPCSV and SPFMV) of SPVD were detected in all places surveyed in Cañete. The wide distribution of SPVD and each of its components in Cañete is thought to be due to the presence of virus sources (infected sweetpotato plants), insect vectors on sweetpotato fields and surrounding crops, and the practice of using infected stem cuttings as planting materials (4). In Peru, farmers produce their own planting materials and move it without sanitary control (unpublished data). Earlier work demonstrated that SPFMV is widespread in Peru $(12,16,23)$ and SPCSV is thought to have been present in Cañete since at least 1993 (12). SPVD-like symptoms were observed in I. setosa graftinoculated with some sweetpotato stemcuttings collected by Cucho (12).

The results indicate that isolates of both SPFMV and SPCSV occur in infected plants in Cañete and that different mixed infection of both virus isolates are present in SPVD-affected plants (Figs. 3 and 4). In this study, two different isolates of SPCSV and three of SPFMV were obtained based on serology, host range, and severity of symptoms on indicator plants. The predominant SPCSV isolate detected in Cañete reacted against MAb mix 1. This is the first report of this serotype outside East Africa (32). It resembles the Ugandan isolate (18), because both SPCSV isolates
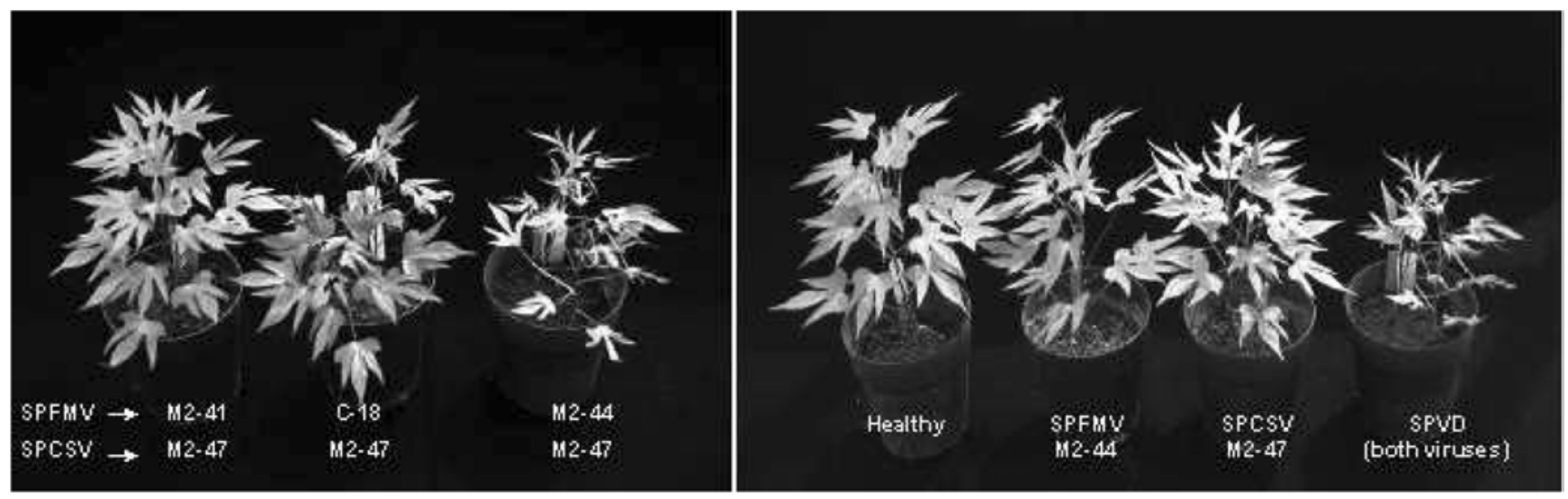

Fig. 4. Symptoms induced by Sweetpotato feathery mottle virus (SPFMV) and Sweetpotato chlorotic stunt virus (SPCSV) isolates, alone and in double infection, in cv. Jonathan. Left: Mix infection of different SPFMV isolates with SPCSV M2-47, showing sweetpotato virus disease symptoms in different degrees. Right: SPFMV and SPCSV isolates selected for field studies; only the plant infected with both viruses showed symptoms.

Table 2. Effect of Sweetpotato feathery mottle virus (SPFMV) and Sweetpotato chlorotic stunt virus (SPCSV), alone and in double infection (sweetpotato virus disease [SPVD]), on some agronomic characteristics of sweetpotato cvs. Jonathan and Costanero, Cañete, Peru (February to July 2000)y

\begin{tabular}{|c|c|c|c|c|}
\hline \multirow[b]{2}{*}{ Cultivar/characteristics ${ }^{\mathrm{z}}$} & \multirow[b]{2}{*}{ Healthy } & \multicolumn{3}{|c|}{ Infected with } \\
\hline & & SPFMV & SPCSV & SPVD \\
\hline \multicolumn{5}{|l|}{ Costanero } \\
\hline Ground cover $\left(\mathrm{cm}^{2} /\right.$ plant $)$ at 46 dap & $1,105.60 \mathrm{a}$ & $1,230.60 \mathrm{a}$ & $795.80 \mathrm{~b}$ & $387.50 \mathrm{c}$ \\
\hline Number of main branches/plant at 160 dap & $3.19 \mathrm{a}$ & $3.06 \mathrm{a}$ & $3.14 \mathrm{a}$ & $3.44 \mathrm{a}$ \\
\hline Main branch length (cm/plant) at 160 dap & $156.75 \mathrm{a}$ & $162.03 \mathrm{a}$ & $142.06 \mathrm{a}$ & $107.00 \mathrm{~b}$ \\
\hline Weight fresh of foliage ( $\mathrm{kg} / \mathrm{plot}$ ) at $167 \mathrm{dap}$ & $51.31 \mathrm{a}$ & $49.67 \mathrm{a}$ & $29.52 \mathrm{~b}$ & $14.56 \mathrm{~b}$ \\
\hline Weight of TSR $(\mathrm{kg} / \mathrm{plot})$ at $167 \mathrm{dap}$ & $36.92 \mathrm{a}$ & $36.34 \mathrm{a}$ & $24.37 \mathrm{~b}$ & $12.83 \mathrm{c}$ \\
\hline Weight of MSR (kg/plot) at 167 dap & $30.51 \mathrm{a}$ & $28.67 \mathrm{a}$ & $19.72 \mathrm{~b}$ & $9.96 \mathrm{c}$ \\
\hline TSR/plot at 167 dap & $282.33 \mathrm{a}$ & $275.00 \mathrm{a}$ & $187.33 \mathrm{~b}$ & $101.33 \mathrm{c}$ \\
\hline MSR/plot at 167 dap & $158.67 \mathrm{a}$ & $146.67 \mathrm{a}$ & $95.33 \mathrm{~b}$ & $51.33 \mathrm{c}$ \\
\hline \multicolumn{5}{|l|}{ Jonathan } \\
\hline Ground cover $\left(\mathrm{cm}^{2} /\right.$ plant $)$ at 46 dap & $1,063.90 \mathrm{a}$ & $922.20 \mathrm{a}$ & $668.10 \mathrm{~b}$ & $359.70 \mathrm{c}$ \\
\hline Number of main branches/plant at 160 dap & $3.36 \mathrm{a}$ & $3.19 \mathrm{a}$ & $3.42 \mathrm{a}$ & $2.81 \mathrm{a}$ \\
\hline Main branch length (cm/plant) at $160 \mathrm{dap}$ & $139.08 \mathrm{a}$ & $138.42 \mathrm{a}$ & $129.28 \mathrm{a}$ & $90.67 \mathrm{~b}$ \\
\hline Weight fresh of foliage $(\mathrm{kg} / \mathrm{plot})$ at 167 dap & $23.90 \mathrm{a}$ & $24.24 \mathrm{a}$ & $14.60 \mathrm{~b}$ & $6.79 \mathrm{~b}$ \\
\hline Weight of TSR $(\mathrm{kg} / \mathrm{plot})$ at 167 dap & $23.34 \mathrm{a}$ & $29.35 \mathrm{a}$ & $13.18 \mathrm{~b}$ & $6.47 \mathrm{c}$ \\
\hline Weight of MSR (kg/plot) at 167 dap & $18.31 \mathrm{a}$ & $22.19 \mathrm{a}$ & $10.64 \mathrm{~b}$ & $5.48 \mathrm{c}$ \\
\hline TSR/plot at 167 dap & $190.33 \mathrm{a}$ & $212.67 \mathrm{a}$ & $101.00 \mathrm{~b}$ & $50.00 \mathrm{c}$ \\
\hline MSR/plot at 167 dap & $81.33 \mathrm{a}$ & $101.00 \mathrm{a}$ & $44.00 \mathrm{~b}$ & $29.00 \mathrm{c}$ \\
\hline
\end{tabular}

${ }_{\mathrm{y}}$ Healthy $=$ virus free. Across rows, means with the same letter do not differ significantly $(P>0.05)$ in the least significant difference test.

${ }^{\mathrm{z}}$ dap $=$ Days after planting, $\mathrm{TSR}=$ total storage roots, and MSR $=$ marketable storage roots. 
react with MAb mix 1 and cause purpling symptoms in sweetpotato plants. The SPCSV serotype MAb mix 2, reported in other countries in the Americas $(13,29,30)$, was also detected in a few samples. For SPFMV, the severity of the M2-44 isolate was reflected in the expression of SPVD symptoms in affected plants when interacting with the M2-47 isolate of SPCSV (Fig. 4).

SwPLV and SPMSV were detected in Cañete with very low frequency (Table 1) but their isolation was unsuccessful, probably due to their erratic distribution in plants.

Although SPCFV, SPMMV, and C-6 were not detected in this study, others have reported their presence in Peru $(12,15)$.

When attempting the correlation between symptoms and virus infection, not all plants showing symptoms reacted positively to any virus by serology. The possible explanations are (i) the low concentration and erratic distribution of viruses in sweetpotato plants $(7,12,14)$; (ii) the presence in the plant tissue of phenolic compounds, latex, and inhibitors that adversely affect serological detection, especially when the plants are quite mature or under hydric stress (1); and (iii) symptoms caused by nonviral factors, such as nutrient disorders (28), senescence, or insect damage. SPFMV often is present at a concentration below the limit of detection by ELISA $(3,7,14,18,32,33)$; therefore, the isolate SPFMV M2-44 was detected only by grafting onto I. setosa, not serologically from infected sweetpotato plants from either greenhouse or field. It also was observed that some symptomless plants reacted positively with one or more of the tested antisera. This might be due to a late infection or to a tolerance of the plant to the virus $(5,12,19,23)$.
This is the first study in Peru to determine the effect of SPFMV and SPCSV, alone and in double infection, on sweetpotato yield. SPFMV-infected cvs. Jonathan and Costanero did not show any symptoms and its effect on the yields of foliage and total storage roots was not significant. SPCSV alone caused significant reductions in sweetpotato yields but, in double infection with SPFMV, caused SPVD and even more drastic yield reduction (Table 1; Fig. 5). Other researchers $(18,21,24,26)$ also observed similar yield losses caused by SPCSV and SPVD. Significant differences among levels of viral infection (healthy plants and infected plants with SPFMV, SPCSV, and SPVD) also were found in the studied agronomic characteristics, as observed by Hahn (21), Milgram et al. (24), and Ngeve and Bouwkamp (26). In this study, SPFMV-infected Jonathan yielded more than did healthy plants, but not significantly so. Carey et al (8) reported a similar result. It is possible that healthy plants developed excessive vegetative growth in detriment of root formation, or that SPFMV conferred a nonspecific protection on the infected plants against adverse conditions and attack by other pathogens (31), permitting a greater yield in comparison with healthy plants.

This study demonstrates the presence of SPVD in Peru and its effect on sweetpotato production, and emphasizes the need to control it by developing a system to produce virus-free planting materials. The Plant Health Authority in Peru was informed of this problem at the beginning of this investigation and public institutions, together with farmers' association, have initiated the respective control measures to prevent the spread of this disease to other sweetpotato-producing areas.

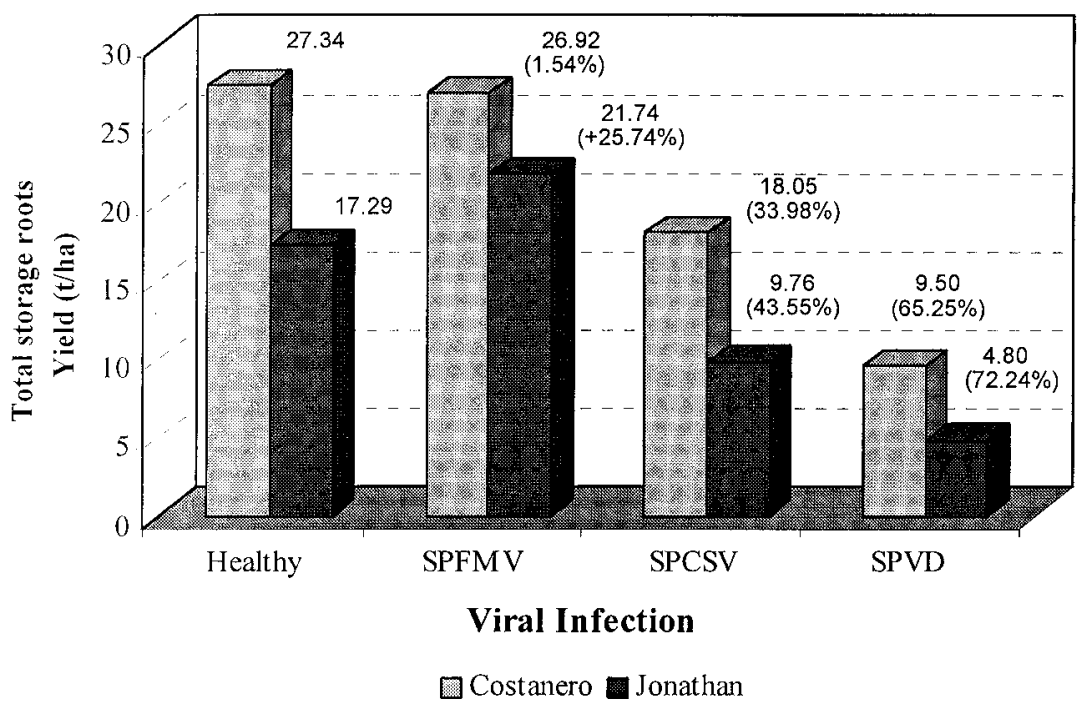

Fig 5. Yield reduction of sweetpotato cvs. Jonathan and Costanero infected with Sweetpotato feathery mottle virus (SPFMV), Sweetpotato chlorotic stunt virus (SPCSV), and sweetpotato virus disease (SPVD) compared with the control (healthy plants). Figures in parentheses show yield reduction compared with the control.

\section{ACKNOWLEDGMENTS}

We thank Instituto Rural Valle Grande of Cañete for collaboration in the survey, the Cañete Farmers' Association for allowing us to carry out the experiment in their fields, J. Vetten and G. Thottappilly for the gift of antibodies, J. P. Molina (INIA-Donoso, Huaral) for facilitating the multiplication of the stem-cuttings of sweetpotato plants, N. Mujica for suggestions on whitefly control during field experiments, and F. de Mendiburu for supporting on the statistical analysis of data.

\section{LITERATURE CITED}

1. Abad, J. A., and Moyer, J. W. 1992. Detection and distribution of sweetpotato feathery mottle virus in sweetpotato by in vitro-transcribed RNA probes (Riboprobes), membrane immunobloting assay, and direct blotting. Phytopathology 82:300-305.

2. Ames, T., Smit, N. E. J. M., Braun, A. R. O'Sullivan, J. N., and Skoglund, L. G. 1996. Sweetpotato: Major Pests, Diseases and Nutritional Disorders. International Potato Center (CIP), Lima, Peru.

3. Aritua, V., Alicai, T., Adipala, E., Carey, E. E., and Gibson, R. W. 1998. Aspects of resistance to sweet potato virus disease in sweet potato Ann. Appl. Biol. 132:387-398.

4. Aritua, V., Legg, J. P., Smit, N. E. J. M., and Gibson, R. W. 1999. Effect of local inoculum on the spread of sweet potato virus disease: limited infection of susceptible cultivars following widespread cultivation of a resistant sweet potato cultivar. Plant Pathol. 48:655661.

5. Biderbost, E., Castellano, P., Williams, L., Di Feo, L., and Nome, F. 1998. A model for the expression of "chlorotic dwarf in agamic progenies of sweet potato plants Fitopatología 33:18 (Abstr. in Spanish)

6. Brunt, A. A., Crabtree, K, Dallwitz, M. J., Gibbs, A. J., and Watson, L. 1996. Viruses of Plants. Descriptions and Lists from the VIDE Database. CAB International, Kew, England.

7. Cadena-Hinojosa, M. A., and Campbell, R. N. 1981. Serologic detection of feathery mottle virus strains in sweet potatoes and Ipomoea incarnata. Plant Dis. 65:412-414.

8. Carey, E. E., Gibson, R. W., Fuentes, S., Machmud, M., Mwanga, R. O. M., Turyamureeba, G., Zhang, L., Ma, D., Abo ElAbbas, F., El-Bedewy, R., and Salazar, L. F 1999. The causes and control of virus diseases of sweetpotato in developing countries: Is sweetpotato virus disease the main problem? Pages 241-248 in: Impact on a Changing World. CIP Program Report 1997-98. CIP, Lima, Peru.

9. CIP (International Potato Center). 2001. Techniques in Plant Virology in CIP. Training Manual Version: 10 January 2001. L. F. Salazar and U. Jayasinghe, eds. CIP, Lima, Peru.

10. Cisneros, F., and Mujica, N. 1999. Biological and selective control of the sweetpotato whitefly, Bemisia tabaci (Gennadius) (Hom.:Aleyrodidae). Pages 255-264 in: Impact on a Changing World. CIP Program Report 1997-98. CIP, Lima, Peru.

11. Clark, C. A., and Moyer, J. W. 1988. Compendium of Sweet Potato Diseases. The American Phytopathological Society, St. Paul, MN.

12. Cucho, F. 1993. Distribution of main sweetpotato (Ipomoea batatas (L.) Lam.) viruses in the south of Peru (Nazca-Cañete). Agronomist thesis. San Luis Gonzaga National University. Ica, Peru. (In Spanish).

13. Di Feo, L., Nome, S. F., Biderbost, E., Fuentes, S., and Salazar, L. F. 2000. Etiology of sweet potato chlorotic dwarf disease in Argentina. Plant Dis. 84:35-39.

14. Esbenshade, P. R., and Moyer, J. W. 1982. Indexing for sweet potato feathery mottle vi- 
rus in sweet potato using enzyme-linked immunosorbent assay. Plant Dis. 66:911-913.

15. Fuentes, S. 1994. Preliminary identification of a sweetpotato virus (C-6). Fitopatología 29:38 (Abstr. in Spanish).

16. Fuentes, S., Arellano, J., and Meza, M. A. 1997. Preliminary studies of a new virus, C-8, affecting sweetpotato. Fitopatología 32:9-10 (Abstr. in Spanish).

17. Fuentes, S., Mayo, M. A., Jolly, C. A., Nakano, N., Querci, M., and Salazar, L. F. 1996. A novel luteovirus from sweetpotato, sweetpotato leaf speckling virus. Ann. Appl. Biol. 128:491-504.

18. Gibson, R. W., Mpembe, I., Alicai, T., Carey, E. E., Mwanga, R. O. M., Seal, S. E., and Vetten, H. J. 1998. Symptoms, aetiology and serological analysis of sweet potato virus disease in Uganda. Plant Pathol. 47:95-102.

19. Gibson, R. W., Mwanga, R. O. M., Kasule, S., Mpembe, I., and Carey, E. E. 1997. Apparent absence of viruses in most symptomless fieldgrown sweetpotato in Uganda. Ann. Appl. Biol. 130:481-490.

20. Hammond, J., Jordan, R. L., Larsen, R. C., and Moyer J. W. 1992. Use of polyclonal antisera and monoclonal antibodies to examine serological relationships among three filamentous viruses of sweetpotato. Phytopathol- ogy $82: 713-717$

21. Hanh, S. K. 1979. Effects of viruses (SPVD) on growth and yield of sweet potato. Exp. Agric. 15:253-256.

22. Karyeija, R. F., Kreuze, J. F., Gibson, R. W., and Valkonen, J. P. T. 2000. Synergistic interactions of a potyvirus and a phloem-limited crinivirus in sweet potato plants. Virology 269:26-36.

23. López, D., and Salazar, L. F. 1987. Studies on sweet potato feathery mottle virus (SPFMV) in Peru. Fitopatología 22:40-41 (Abstr. in Spanish).

24. Milgram, M., Cohen, J., and Loebenstein, G. 1996. Effects of Sweet potato feathery mottle virus and Sweet potato sunken vein virus on sweet potato yields and rates of reinfection of virus-free planting material in Israel. Phytoparasitica 24:189-193.

25. Moyer, J. W., and Salazar, L. F. 1989. Viruses and viruslike diseases of sweet potato. Plant Dis. 73:451-455.

26. Ngeve, J. M., and Bouwkamp, J. C. 1991. Effects of sweet potato virus disease (SPVD) on the yield of sweet potato genotypes in Cameroon. Exp. Agric. 27:221-225.

27. Oficina de Información Agraria (OIA). 2001. Estadística Agraria-Lima. Ministerio de Agricultura, Perú.
28. O'Sullivan, J. N., Asher, C. J., and Blamey, F. P. C. 1997. Nutrient disorders of sweet potato Monogr. No 48. Australian Centre for International Agricultural Research (ACIAR), Canberra, Australia.

29. Pio-Ribeiro, G., Winter, S., Hamilton, R. I. De Assis Filho, F. M., and Da Paz, C. D. 1994. First report of sweetpotato viruses disease-Associated Closterovirus in Brazil. Plant Dis. 78:1122.

30. Pio-Ribeiro, G., Winter, S., Jarret, R. L., Demski, J. W., and Hamilton, R. I. 1996. Detection of sweet potato virus disease-associated closterovirus in a sweet potato accession in the United States. Plant Dis. 80:551-554.

31. Salazar, L. F. 1996. Potato Viruses and Their Control. International Potato Center (CIP), Lima, Peru.

32. Vetten, H. J., Hoyer, U., Maiss, E., Lesemann, D. E., and Jelkmann, W. 1996 Serological detection and discrimination of geographically diverse isolates of sweet potato sunken vein closterovirus. (Abstr.) Phytopathology 86:S100.

33. Winter, S., Purac, A., Leggett, F., Frison, E. A., Rossel, H. W., and Hamilton, R. I. 1992. Partial characterization and molecular cloning of a closterovirus from sweetpotato infected with the sweetpotato virus disease complex from Nigeria. Phytopathology 82:869-875. 